\title{
Quality Properties and Anti-allergic Effect of Makgeolli Added with Garlic
}

\author{
Yu-Jin Ko', Sang-Dong Kang', Sang-Tae Kang ${ }^{2}$ and Chung-Ho Ryu'* \\ ${ }^{1}$ Division of Applied Life Science (BK21 program), Institute of Agriculture and Life Science, Gyeongsang National University, Jinju 660-701, \\ Korea \\ ${ }^{2}$ Green Treasure Island Brewery Co. LTD, Namhae, 668-882, Korea
}

Received September 26, 2011 /Revised November 11, 2011 /Accepted November 11, 2011

\begin{abstract}
Allium sativum, commonly known as garlic, is well known for its antibacterial, antioxidant, and hypotensive activities, as well as its antiaging bioactive properties. This study investigated the physicochemical properties and anti-allergic effects of garlic in order to develop a method to produce Makgeolli using garlic. Levels of total sugar, reducing sugar contents, total acid and amino acid contents of garlic Makgeolli were higher than those of the control (normal Makgeolli without garlic), and its alcohol content was 7.0\%. Polyphenol contents, DPPH (1, 1-diphenyl-2-picryl-hydrazyl) free radical scavenging activity and total thiosulfate contents of garlic Makgeolli were a bit higher than those of the control. The main organic acids of garlic Makgeolli were lactic, citric, malic, oxalic and succinic acids. Especially, lactic acid content was 16 fold higher than the control. According to MTT assay, garlic Makgeolli had no significant effect on the viability of human mast cells, and secretion of histamine was more effectively inhibited by garlic Makgeolli than by the control. Garlic Makgeolli was superior to the control in all results of sensory characteristics except in color. Therefore, the anti-oxidant activity and anti-allergic effect of garlic Makgeolli could improve the quality of Korean Makgeolli.
\end{abstract}

Key words : Makgeolli, garlic, fermentation, anti-allergy

\section{서 론}

세계 각국에는 그 지역마다 다양한 민속주 또는 전통주가 전해져 내려오고 있으며, 우리나라의 경우 약탁주 등이 제조 되고 있다. 막걸리의 역사는 삼국사기시대부터 기록되어 있으 며 막거른 술이라는 데서 비롯된 것으로 맑지 않고 탁하다 하여 탁주라 부르기도 하고 식량대용 또는 갈증해소 목적으로 농부들이 애용해 왔으므로 농주라고 부르기도 한다[30]. 막걸 리는 곡류와 누룩을 이용하여 양조한 후 증류하지 않고 마시 는 술이며, 다른 주류와는 달리 당질, 무기질, 비타민과 lysine, leucine, glutamic acid, proline 및 glutathione 등의 아미노산 이 풍부한 독특한 술이며 최종제품의 알코올 함량은 $6 \%$ 정도 이다 $[7,17,29]$. 발효가 완전히 끝나지 않은 상태로 유통 - 판매 되기 때문에 상품의 변질이 쉬우며 저장기간이 짧고, 발효 시 발생되는 향미와 건강 기능성을 생각하는 소비자들의 높은 기호도 때문에 막걸리의 한식 세계화 추진과 함께 막걸리 시 장이 급성장하는 추세이다[14]. 현재 막걸리에 대한 연구는 작 업 공정의 개선[18,22,30] 묵은 쌀과 벼 도정 부산물을 이용한 탁주 제조[9,23] 탁주 제조시 생성되는 부산물을 이용한 연구 $[8,16]$ 및 휘발성 향기분석이 대부분이다 $[5,20,21]$.

생활수준이 향상됨에 따라 건강에 대한 관심이 높아지고

*Corresponding author

Tel : +82-55-772-1905, Fax : +82-55-772-1909

E-mail : ryu@gnu.ac.kr
약리적 기능성을 강화시킨 청주, 약주를 원하는 소비자가 증 가하고 있는 추세이며 최근에는 건강 보조 및 질병 예방 등 기능성을 가지는 인삼, 오미자, 산수유, 매실, 당귀, 상황버섯, 구기자 등을 이용한 발효주의 개발과 효능에 관한 연구가 이 루어지고 있다[13,25]. 하지만 소비자들의 높은 기호도를 충족 시키기 위해서는 막걸리의 기능성 연구와 첨가물을 통한 품질 개선에 대한 연구가 필요하다[13,19,25].

본 연구에서 사용한 마늘은 동양의 대표적인 식품원료일 뿐만 아니라 건강식품으로 알려져 있으며 많은 연구를 통하 여 항균 및 살균작용, 항산화작용, 혈압 강하작용, 소화촉진, 피부질환 및 노화억제작용이 알려져 있다[26,27]. 또한 마늘 에 함유된 allicin, germanium, cysteine 등은 항균, 암세포 생 육 억제 작용 및 항알레르기 작용이 있는 것으로 알려져 있 다[3,6].

따라서 본 연구에서는 다양한 기능성 및 생리활성 물질을 함유하고 있는 마늘의 활용방안을 제시하고 마늘 생산 농가의 안정적인 소득과 수급조절 및 건강 기능 증진을 위하여 마늘 을 첨가한 막걸리를 제조하고 마늘 첨가 막걸리의 품질 특성 과 항알레르기 효과를 조사하고자 한다.

\section{재료 및 방법}

\section{실험재료}

막걸리 제조용 쌀은 경남 진주지역에서 생산되는 것을 단위 농협에서 구입하여 도정기(Deahwa, Korea)로 $15 \%$ 를 도정하 
여 원료미로 사용하였고, 쌀국은 경남 진주시 진주공동탁주에 서 고두밥에 백국균(Aspergillus niger var. kawachii)을 배양시 켜 제조한 것을 사용하였다. 마늘은 2009년 6월경 경남 남해지 역에서 수확한 마늘을 $100^{\circ} \mathrm{C}$ 에서 10 분간 증자한 후 파쇄하여 사용하였다.

\section{효모 배양}

막걸리를 제조하기 위해 Saccharomyces cerevisiae KCCM 12648을 YM (Difico, USA) 배지에 배양한 후 YPD (yeast extract $1 \%$, peptone $1 \%$, glucose $2 \%, \mathrm{pH} 3.8$ )에 $1 \times 10^{9}$ $\mathrm{CFU} / \mathrm{ml}$ 접종하여 24 시간 동안 $30^{\circ} \mathrm{C}$ 에서 $190 \mathrm{rpm}$ 으로 진 탕배양하였다.

\section{마늘 첨가 막걸리 제조}

마늘 첨가 막걸리를 제조하기 위하여 개량식 국 $0.5 \mathrm{~kg}$ 을 0.71 의 물에 잘 혼합하고 효모 $1 \%$ 를 접종하여 주모를 제조하 였으며 주모를 확대 배양하기 위하여 국 $1.5 \mathrm{~kg}$ 과 81 의 물을 첨가하여 24 시간 동안 배양하였다. 쌀 $14 \mathrm{~kg}$ 을 세척하여 3 시간 물에 침지한 후 물을 빼고 $121^{\circ} \mathrm{C}$ 에서 30 분간 증자한 후 $25^{\circ} \mathrm{C}$ 에서 냉각하여 고두밥을 제조하였다. 제조된 고두밥에 물 261 를 첨가하여 본 담금을 실시하고 $25^{\circ} \mathrm{C}$ 에서 4 일간 발효 시킨 후 $100^{\circ} \mathrm{C}$ 에서 10 분간 블랜칭한 마늘 $12 \%(\mathrm{v} / \mathrm{v})$ 를 첨가 (효모의 생육을 저해하지 않으며, 최적의 관능적 특징을 가진 마늘 첨가 농도, data not shown)하고 $25^{\circ} \mathrm{C}$ 에서 3 일간 배양하 였다. 발효가 끝난 마늘 첨가 막걸리를 $60^{\circ} \mathrm{C}$ 에서 15 분간 살균 하여 실험에 사용하였다. 대조구로는 마늘을 첨가하지 않은 막걸리를 제조하였다. 제조된 막걸리는 원심분리, 여과, 농축 후 동결건조하여 냉장실에 보관하면서 세포실험의 시료로 사 용하였다.

\section{이화학적 특성}

발효 과정 중 $\mathrm{pH}$ 변화는 $\mathrm{pH}$ meter (Orion 420A, USA)로 측정하였으며, 총산함량은 $0.1 \mathrm{~N} \mathrm{NaOH}$ 용액으로 중화 적정 하여 succinic acid로 환산하였고, 당도는 hand refractometer (KRÜSS, Germany)를 이용하여 측정하였다. 알코올 함량은 $\mathrm{AOAC}$ 법[1]에 따라 시료 $100 \mathrm{ml}$ 를 증류한 후 $15^{\circ} \mathrm{C}$ 에서 주정계 를 이용하여 측정하였으며 총당 함량은 $\mathrm{Phenol}-\mathrm{H}_{2} \mathrm{SO}_{4}$ 법[10] 에 따라 시료 $1 \mathrm{ml}$ 에 $5 \%$ phenol $1 \mathrm{ml}$ 와 $\mathrm{H}_{2} \mathrm{SO}_{4} 5 \mathrm{ml}$ 를 가한 뒤 상온에서 30 분간 반응 후 $460 \mathrm{~nm}$ 에서 흡광도를 측정하였 고, 표준물질로 glucose (Merck, Germany)를 사용하였다. 환 원당은 DNS (3,5-dinitrosalicylic acid)법[2]을 사용하여 시료 $1 \mathrm{ml}$ 에 $0.75 \% \mathrm{DNS}$ 용액 $1 \mathrm{ml}$ 을 첨가하고 $100^{\circ} \mathrm{C}$ 에서 5 분간 반응시킨 다음 증류수 $8 \mathrm{ml}$ 을 가한 후 $540 \mathrm{~nm}$ 에서 흡광도를 측정하였다. 유기산 함량은 시료를 원심분리 $(8,000 \times \mathrm{g} 10 \mathrm{~min}$, Hanil Micro 17R, Korea)하여 침전물을 제거한 후 $60 \%$ perchloric acid를 $50 \mu 1$ 을 첨가하여 $0.22 \mu \mathrm{m}$ membrane filter
(Millipore, USA)로 여과하였다. Sep-pak $\mathrm{C}_{18}$ (Waters, USA)로 여액에서의 색소 및 단백질 성분을 제거한 후 HPLC (Agilent 1100 Series, USA)로 분석하였다. 분석용 column은 C-610H (300 mm×7.8 mm $\times 9 \mu \mathrm{m}$, Supelco, USA)을 이용하였고, 이동 상은 $0.1 \%$ phosphoric acid를 이용하였으며 flow rate는 0.5 $\mathrm{ml} / \mathrm{min}$, detector는 UV detector를 이용하여 $210 \mathrm{~nm}$ 에서 검 출하였다. 또한 색도 측정은 Chromameter (Minolta CT 310, Japan)를 이용하여 L (명도), a (적색도) 및 b (황색도) 값으로 측정하였다.

\section{항산화 활성 측정}

마늘 첨가 막걸리의 항산화 활성을 정량적으로 분석하기 위하여 total polyphenol 함량과 DPPH 자유라디칼(Free radi$\mathrm{cal}$ ) 소거활성을 측정하였다. Total polyphenol 함량은 folin-Denis법[2]을 사용하였다. 즉 25배로 희석한 시료 $5 \mathrm{ml}$ 에 folin 시약 $5 \mathrm{ml}$ 를 첨가하여 잘 섞은 후 3 분간 정치한 다음 $10 \% \mathrm{Na}_{2} \mathrm{CO}_{3}$ 용액 $5 \mathrm{ml}$ 을 넣고 1 시간 동안 정치하고 spectrophotometer (UV-1601, Shimadzu, Japan)를 사용하여 760 $\mathrm{nm}$ 에서 흡광도를 측정하였으며 표준물질로는 (+)catechin (Sigma, USA)을 사용하였다. DPPH 자유라디칼 소거활성은 Kilani 등[11]의 방법에 준하여 시료 $1 \mathrm{ml}$ 에 $0.2 \mathrm{mM} \mathrm{DPPH}$ (1,1-diphenyl-2- picrylhydrazy, Sigma Chemical, USA) 용액 을 $2 \mathrm{ml}$ 첨가하여 실온에서 30 분간 반응시킨 후 $517 \mathrm{~nm}$ 에서 흡광도를 측정하였다. 자유라디칼 소거 활성은 다음과 같이 계산하였다.

Scavenging activity $(\%)=\left(1-A_{1} / A_{0}\right) \times 100$

$\mathrm{A}_{1}$ : 처리군 시료의 흡광도

$\mathrm{A}_{0}$ : 대조군 시료의 흡광도

Total thiosulfate 함량 측정

Allin의 분해 생성물인 thiosulfate는 마늘 분쇄물 $1 \mathrm{~g}$ 에 3 배 량의 냉각수를 가하여 신속히 마쇄, 추출, 여과하였다. 이 여액 $2 \mathrm{ml}$ 에 2 배량의 흡광분석용 hexane을 가해 2 분간 진탕 추출 한 다음 hexane층을 취하여 $254 \mathrm{~nm}$ 에서 흡광도 측정하고, 마 늘 $\mathrm{g}$ 당 상대적인 흡광도 값으로 나타내었다[4].

\section{세포 배양}

항알레르기 실험에 사용된 세포는 인간유래 비만세포주인 HMC-1 세포(Human mast cell line, a kind gift from Dr. H. M. Kim at Kyeonghee Universiry, Seoul, Korea)를 사용하였고 Isocove's modified Dulbecco's medium (IMDM: GIBCO, USA)에 $10 \%$ fetal bovine serum과 $100 \mathrm{U} / \mathrm{ml}$ 의 penicillin과 $100 \mu \mathrm{g} / \mathrm{ml}$ 의 streptomycin (Pen Strep, Gibco, USA)를 첨가한 배지에서 $5 \% \mathrm{CO}_{2}$ incubator, $37^{\circ} \mathrm{C}$ 로 배양하였다. 


\section{세포 생존율 측정}

HMC-1 세포를 사용하여 마늘 첨가 막걸리와 대조구 막걸 리 자체성분이 세포 생육에 미치는 효과를 조사하기 위하여 MTT (3-(4,5-dimethylthiazol-2-yl)-2,5-diphenyl-tetrazolium bromide) assay로 실험하였다[15]. HMC- 1 세포 $\left(5 \times 10^{5}\right.$ cell $/ \mathrm{ml})$ 에 ethanol을 제거한 마늘 첨가 막걸리 액 $(1 \mathrm{mg} / \mathrm{ml})$ 을 처리한 후 phorbol 12-myristate 13-acetate (PMA, Sigma, USA)와 calcium ionophore A23187 (Sigma, USA)로 8 시간 동안 자극시켰다. 자극 후 MTT solution $(50 \mu \mathrm{l})$ 를 첨가하여 $37^{\circ} \mathrm{C}$ 에서 overnight하고 dimethyl sulfoxide (DMSO)을 이용 하여 결정을 녹인 후 $540 \mathrm{~nm}$ 에서 흡광도를 측정하였다. PMA 와 $\mathrm{A} 23187$ 만을 처리한 대조구의 흡광도를 $100 \%$ 로 하여 세포 생존율을 환산하였다.

\section{Histamine 유리량 측정}

마늘 첨가 막걸리의 histamine 유리억제효과 및 유리량을 정량적으로 확인하기 위하여 histamine EIA (Enzyme Immunoassay) Kit (EA31, Oxford, USA)를 이용하였다. Histamine 유리량을 in vitro 실험으로 확인하기 위하여 HMC-1 세포를 이용하였다. 즉, HMC-1 세포를 $1 \times 10^{6} \mathrm{cell} / \mathrm{ml}$ 로 조절하여 24 well plate의 각 well에 $500 \mu \mathrm{l}$ 씩 분주하여 overnight 배양해서 세포를 안정화 시킨 후 마늘 첨가 막걸리 (final concentrate $1 \mathrm{mg} / \mathrm{ml}$ )를 첨가하고 1 시간 반응 후 각 well에 자극제(A23187+PMA)를 처리하여 8 시간 반응시킨 배 양액을 $5,000 \mathrm{rpm}, 5$ 분간 원심분리 후 상징액을 histamine 측정용 시료로 사용하였다. Monoclonal anti-histamine antibody가 코팅된 96 well plate에 $50 \mu 1$ 의 샘플 및 standard를 넣은 후 enzyme conjugate $50 \mu 1$ 를 첨가하여 혼합하고 45 분간 실온에서 방치 후 washing buffer로 3회 세척하고 substrate (TMB)를 $150 \mu \mathrm{l}$ 첨가하여 잘 흔들어 섞고 15 20 분간 반응시 킨 후 $1 \mathrm{~N} \mathrm{HCl}$ 용액 $50 \mu 1$ 를 넣어 반응을 종료하고 $450 \mathrm{~nm}$ 에서 흡광도를 측정하였다.

Histamine release inhibition $(\%)=(A-B) / A \times 100$
$\mathrm{A}$ : 대조군 시료의 흡광도
$\mathrm{B}$ : 처리군 시료의 흡광도

\section{관능평가}

관능검사는 관능평가 법에 대한 사전 교육을 시킨 23 40세 남, 여 20명의 패널을 선정하여 마늘첨가 막걸리의 색, 향, 신 맛, 떫은맛, 전체적 기호도를 5점 평점법[9]으로 평가하여 매우 좋다 5 , 매우 나쁘다 1 의 점수로 표시하였다.

\section{통계처리}

각 실험은 3 회 반복 검정하여 실험 군당 평균(mean)표준 오차(standard)로 표시하였다.

\section{결과 및 고찰}

\section{마늘 첨가 막걸리의 품질특성}

마늘을 첨가한 막걸리와 대조구 막걸리의 품질특성을 비교 하여 Table 1에 나타내었다. 마늘 첨가 막걸리의 총당 및 환원 당 함량은 각각 $9.60,1.00 \%$ 로 나타나 대조구 막걸리에 비해 다소 높게 나타났으며, $\mathrm{pH}$ 는 4.05로 대조구와 유사한 수치를 보여 마늘 첨가가 $\mathrm{pH}$ 에 큰 영향을 미치지 않음을 알 수 있다. Shin 등[28]은 율무를 첨가한 막걸리의 초기 $\mathrm{pH}$ 가 3.0 3.6에서 7일 후 3.6 3.8로 증가하고, 첨가량이 많을수록 $\mathrm{pH}$ 가 높다고 보고하여 본 연구의 결과와 다소 차이가 있었으나 이는 첨가 물에 따른 차이로 생각된다. 산도는 대조구인 $0.21 \%$ 보다 2 배 높은 $0.42 \%$ 로 나타났고 아미노산도는 약 7 배 높은 $1.79 \%$ 였으 며, 알코올 함량은 $7 \%$ 로 대조구 막걸리보다 $1 \%$ 높게 나타났 다. Kim 등[12]은 막걸리에 감초를 첨가할 경우 첨가된 감초 성분에 의해 탁주의 산도가 떨어지지만 효모나 젖산균 등의 미생물에 의해 산도가 증가한다고 보고하여 본 실험의 결과와 는 다소 차이를 보였다. 마늘 첨가 막걸리의 아미노산도가 높 은 이유는 마늘에서 asparagines, arginine, glutamic acid, proline, aspartic acid, glycine 등의 다양한 아미노산이 발효 과정을 거치면서 용출되었기 때문이라 사료된다.

\section{마늘 첨가 막걸리의 유기산 함량}

마늘 첨가 막걸리와 대조구 막걸리의 유기산 함량은 Table 2에 나타내었다. 마늘 첨가 막걸리의 주요 유기산은 lactic, citric, malic, oxalic 및 succinic acid 순으로 나타났으며 각각 203.2, 82.0, 62.7, 46.5 및 $2.2 \mathrm{mg} \%$ 로 나타났으나 대조구 막걸리 의 주요 유기산은 citric, lactic, oxalic, lactic 및 succinic acid 순으로 나타났다. Joung 등[9]은 일반미로 만든 막걸리에서는 succinic, citric, acetic 및 lactic acid 등이 검출된다고 보고하여 본 연구의 결과와는 다소 차이를 보였다. 마늘 첨가 막걸리의 유기산 함량이 대조구 막걸리에 비해 높게 나타나는 것은 마 늘에서 유래된 유기산에 의한 것으로 생각된다. 생마늘에는 citric, malic, lactic 및 oxalic acid가 각각 331.4, 173.6, 84.5, $30.6 \mathrm{mg} \%$ 가 포함되어있으며 저장기간 중 citric, malic acid는

Table 1. Quality properties of Makgeolli added with garlic

\begin{tabular}{lcc}
\hline & MG & M \\
\hline Total sugar (\%) & $9.60 \pm 0.56^{1}$ & $5.20 \pm 0.42$ \\
Reducing sugar (\%) & $1.00 \pm 0.12$ & $0.90 \pm 0.13$ \\
pH & $4.05 \pm 0.11$ & $3.91 \pm 0.03$ \\
Total acidity (\%) & $0.42 \pm 0.08$ & $0.21 \pm 0.04$ \\
Amino acidity (\%) & $1.79 \pm 0.02$ & $0.26 \pm 0.03$ \\
Ethanol contents (\%) & $7.00 \pm 0.14$ & $6.00 \pm 0.22$ \\
\hline
\end{tabular}

${ }^{1}$ Means \pm S.D
MG: Makgeolli added with garlic; M: Normal Makgedli as a con-
trol 
Table 2. Organic acid contents of Makgeolli added with garlic

\begin{tabular}{lcccc}
\hline & \multicolumn{2}{c}{ MG } & \multicolumn{2}{c}{ M } \\
\cline { 2 - 5 } & $\begin{array}{c}\text { Contents } \\
(\mathrm{mg} \%)\end{array}$ & $\begin{array}{c}\text { Total } \\
\text { rate }(\%)\end{array}$ & $\begin{array}{c}\text { Contents } \\
(\mathrm{mg} \%)\end{array}$ & $\begin{array}{c}\text { Total } \\
\text { rate }(\%)\end{array}$ \\
\hline Oxalic acid & $46.5 \pm 1.2^{1}$ & 11.7 & $6.6 \pm 0.4$ & 9.5 \\
Malic acid & $62.7 \pm 4.4$ & 15.8 & $4.4 \pm 1.3$ & 6.4 \\
Citric acid & $82.0 \pm 5.4$ & 20.7 & $45.5 \pm 5.8$ & 65.5 \\
Lactic acid & $203.2 \pm 10.2$ & 51.2 & $12.4 \pm 2.2$ & 17.9 \\
Succinic acid & $2.2 \pm 6.8$ & 0.6 & $0.5 \pm 0.4$ & 0.7 \\
\hline Total & $396.6 \pm 8.02$ & 100 & $69.3 \pm 6.1$ & 100
\end{tabular}

\section{${ }^{1}$ Means \pm S.D}

MG: Makgeolli added with garlic; M: Normal Makgeolli as a control

감소하고 lactic acid는 증가하는 것으로 알려져 있다[31].

\section{마늘 첨가 막걸리의 색도}

발효가 끝난 마늘 첨가 막걸리와 대조구 막걸리의 색도변화 를 측정하여 Table 3에 나타내었다. 마늘 첨가 막걸리의 명도 L값은 89.52로 대조구 막걸리의 L값 27.51 보다 높게 나타나 대조구 막걸리에 비해 백색을 가지는 것으로 나타났으며 적색 도 $\mathrm{a}$ 값과 황색도 $\mathrm{b}$ 값은 각각 $0.25,0.33$ 와 $4.12,6.40$ 으로 유사하 게 나타났다. Kim 등[12]은 감초를 탁주에 첨가할 경우 첨가량 에 따른 $\mathrm{L}$ 값과 적색도의 차이는 보이지 않았고 감초 첨가량이 증가 할수록 황색도가 높게 나타났으며, 황색도의 증가는 첨 가 원료인 감초의 황색도가 높기 때문이라 보고하였다. 따라 서 마늘 첨가 막걸리의 L값이 높은 것은 첨가되는 마늘의 고형 분에 의한 것으로 생각된다. 일반적으로 탁주의 색도는 첨가 되는 재료에 의해 영향을 많이 받는데 마늘을 첨가할 경우 특유한 백색을 가지는 막걸리를 생산 할 수 있을 것으로 사료 된다.

\section{마늘 첨가 막걸리의 항산화 활성}

마늘 첨가 막걸리와 대조구 막걸리의 $\mathrm{DPPH}$ 자유라디칼 소거 활성, total polyphenol 및 total thiosulfate 함량을 Fig. 1 에 나타내었다. 마늘 첨가 막걸리의 $\mathrm{DPPH}$ 자유라디칼 소거 활성 및 total polyphenol 함량은 각각 $45 \%, 34 \%$ 로 대조구 막 걸리의 $8 \%, 12 \%$ 에 비해 높게 나타났다. 또한 total thiosulfate 함량을 $\mathrm{OD}$ 값으로 나타내었을 때 마늘 첨가 막걸리가 0.17 $\mathrm{OD} / \mathrm{g}$ 으로 나타났고 대조구 막걸리가 $0.048 \mathrm{OD} / \mathrm{g}$ 으로 나타

Table 3. Color values of Makgeolli added with garlic

\begin{tabular}{lcc}
\hline & MG & M \\
\hline L value (Lightness) & $89.52 \pm 0.12^{1}$ & $27.51 \pm 0.09$ \\
a value (Redness) & $0.25 \pm 0.06$ & $0.33 \pm 0.14$ \\
b value (Yellowness) & $4.12 \pm 0.10$ & $6.40 \pm 0.64$ \\
\hline
\end{tabular}

${ }^{1}$ Means \pm S.D

MG: Makgeolli added with garlic; M: Normal Makgeolli as a control

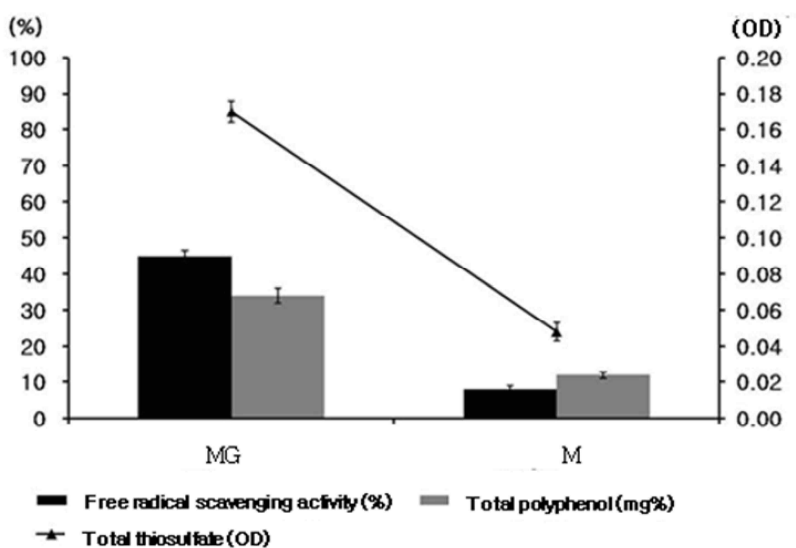

Fig. 1. DPPH free radical scavenging activity, total polyphenol and total thiosulfate contents of Makgeolli added with garlic. MG: Makgeolli added with garlic; M: Normal Makgeolli as a control

나는 것을 확인했다. Ryu 등[24]은 시판전통주의 $\mathrm{DPPH}$ 자유 라디칼 제거 활성을 분석하였을 때 하나의 실험구에서만 미약 한 활성을 나타낸다고 보고하여 일반 막걸리 중 기능성을 가 지는 제품은 부족한 것으로 사료되며 막걸리에 마늘을 첨가할 경우 항산화 활성이 증가하기 때문에 마늘 첨가 막걸리의 기 능성을 기대할 수 있을 것으로 생각된다. 또한 마늘에 함유되 어 있는 유기 황 화합물에 의해 $\mathrm{DPPH}$ 자유라디칼 소거 활성 및 polyphenol 함량이 높게 나타나는 것으로 생각되며, 마늘 의 alliin 분해 산물인 thiosulfate는 생마늘에서 allinase에 의 해 매우 빠르게 자가반응하는 화합물로써 첨가되는 마늘의 전처리 과정 중에 생성된 것으로 사료된다[4].

\section{마늘 첨가 막걸리의 세포 생존률}

MTT 시약이 살아있는 세포와 반응하여 보라색의 formazan을 형성하는 원리를 이용하여 마늘 첨가 막걸리와 대조 구 막걸리를 최종농도 $1 \mathrm{mg} / \mathrm{ml}$ 이 되도록 $\mathrm{HMC}-1$ 세포에 처 리한 다음 MTT solution을 첨가하여 $37^{\circ} \mathrm{C}$ 에서 overnight 배양 한 후 착생된 생존 HMC-1 세포만을 계수하여 세포 생존율을 Fig. 2에 나타내었다. 자극제만을 처리한 $\mathrm{B}$ 구, 마늘 첨가 막걸 리 처리구 및 대조구 막걸리 처리구가 HMC-1 세포 생존율에 미치는 영향을 자극제를 처리하지 않은 정상세포 즉 대조구 $\mathrm{C}$ 구를 $100 \%$ 로 환산한 결과 마늘 첨가 막걸리는 $80 \%$, 대조구 막걸리는 $82 \%$ 로 나타나 유의적 차이를 보이지 않아 마늘 첨가 막걸리에 의한 세포 독성이 없음을 추정할 수 있었다.

\section{마늘 첨가 막걸리의 histamine 유리억제효과}

마늘 첨가 막걸리와 대조구 막걸리를 HMC-1 세포에 처리 하여 유리되는 histamine을 측정한 결과를 Fig. 3에 나타내었 다. 마늘 첨가 막걸리와 대조구 막걸리를 HMC-1 세포에 최종 농도 $1 \mathrm{mg} / \mathrm{ml}$ 이 되도록 처리한 후 histamine 유리억제량을 


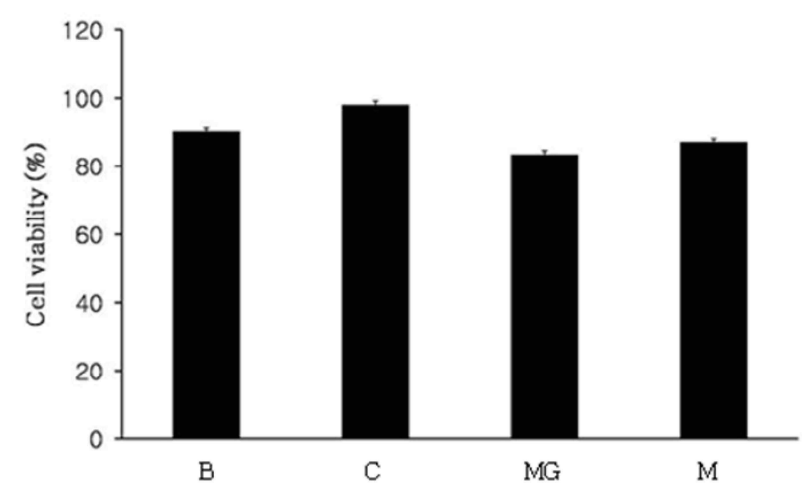

Fig. 2. Effect of Makgeolli added with garlic on Cell viability. B (blank), stimulated by PMA plus A23187; C (control), non treatment; MG, Makgeolli added with garlic; M: Normal Makgeolli as a control. Sample $1 \mathrm{mg} / \mathrm{ml}$ (final concentrate) were treated before $30 \mathrm{~min}$ of stimulating PMA plus A23187.

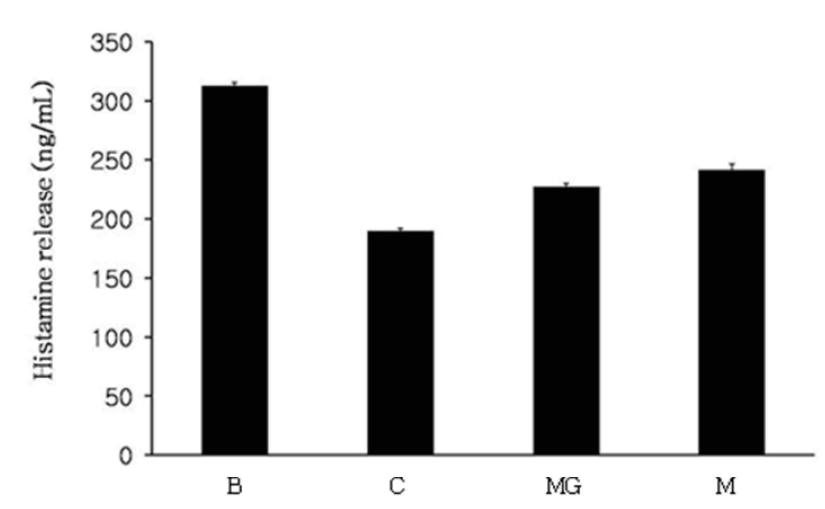

Fig. 3. Effect of Makgedli added with garlic on histamine release in stimulated HMC-1. B (blank), stimulated by PMA plus A23187; C (control), non treatment; MG, Makgeolli added with garlic; M: Normal Makgeolli as a control. Sample $1 \mathrm{mg} / \mathrm{ml}$ (final concentrate) were treated before $30 \mathrm{~min}$ of stimulating PMA plus A23187.

측정한 결과, 마늘 첨가 막걸리 처리구는 $241 \mathrm{ng} / \mathrm{ml}$ 유리량을 보였으며, 대조구 막걸리는 $227 \mathrm{ng} / \mathrm{ml}$ 유리량을 보였다. Histamine 유리량을 정량한 결과를 무처리구에 대한 histamine 유리억제효과로 환산하여 Fig. 4에 나타내었다. 마늘 첨 가 막걸리와 대조구 막걸리의 histamine 유리억제율을 환산한 결과, 대조구 B (자극제 $\mathrm{PMA}+\mathrm{A} 23187$ )와 비교해 마늘 첨가 막걸리와 대조구 막걸리는 각각 $27 \%$ 와 $22 \%$ 의 억제율을 나타 내어 마늘 첨가 막걸리의 histamine 유리억제효과가 다소 높 음을 확인할 수 있었다. 마늘을 첨가하여 제조한 막걸리가 대 조구 막걸리에 비해 뛰어난 항염증 효과를 나타내는 것으로 확인되었다.

\section{마늘 첨가 막걸리의 관능평가}

마늘을 첨가하여 제조된 막걸리의 색, 향, 맛, 전체적 기호도

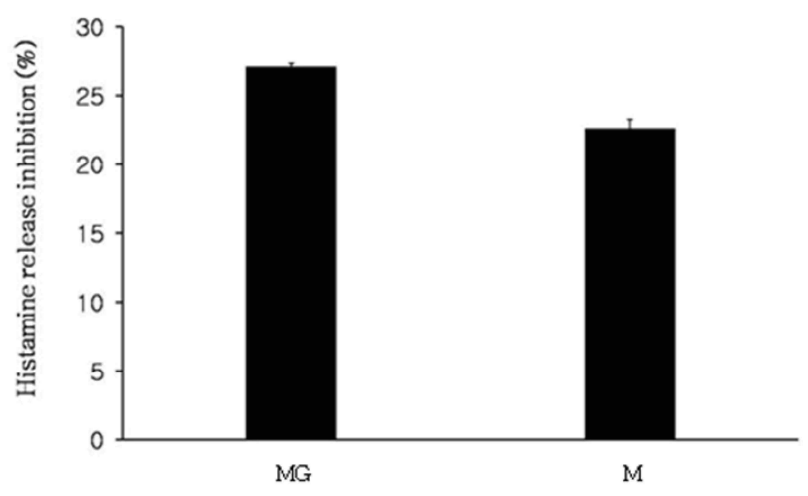

Fig. 4. Histamine release inhibition of Makgeolli added with garlic. MG, Makgeolli added with garlic; M: Normal Makgeolli as a control. Sample $1 \mathrm{mg} / \mathrm{ml}$ (final concentrate) were treated before $30 \mathrm{~min}$ of stimulating PMA plus A23187.

Table 4. Sensory evaluation of Makgeolli added with garlic

\begin{tabular}{lcc}
\hline & MG & M \\
\hline Color & $5.30 \pm 0.81^{1}$ & $6.20 \pm 0.05$ \\
Flavor & $4.70 \pm 0.12$ & $3.20 \pm 0.09$ \\
Taste & $6.10 \pm 0.06$ & $4.50 \pm 1.03$ \\
Overall acceptability & $5.90 \pm 0.12$ & $5.20 \pm 0.20$ \\
\hline
\end{tabular}

\section{${ }^{1}$ Means \pm S.D}

MG: Makgeolli added with garlic; M: Normal Makgedli as a control

를 조사하여 Table 4에 나타내었다. 색에 대한 기호도는 마늘 을 첨가하지 않은 대조구가 6.20으로 마늘 첨가 막걸리보다 높았다. 첨가된 마늘성분에 의한 색상의 변화가 기호도를 감 소시키는 것으로 생각된다. 향, 맛, 전체적 기호도는 각각 4.70, 6.10 및 5.90로 대조구 막걸리 보다 높게 나타났다. 마늘 첨가 막걸리의 기호도가 높은 것은 마늘이 발효 되면서 특유의 강 한 향이 사라지고 막걸리의 전체적인 향을 상승시키며 마늘에 첨가된 phenol 계 성분이 용출되어 약간의 쓴맛과 떫은맛을 더하기[4] 때문이라 생각된다. 관능평가 결과 색상을 제외한 모든 평가에서 마늘 첨가 막걸리가 대조구 막걸리에 비해 전 반적으로 우수한 평가결과를 보여 막걸리 시장에서 경쟁력을 가질 수 있을 것으로 기대된다.

\section{감사의 글}

본 연구는 BK21 program 지원으로 수행되었기에 이에 감사 드립니다.

\section{References}

1. AOAC. 1990. Official methods of analysis. 15th eds. Association of official analytical chemists. Washington $D C$. 
2. Ann, Y. G. and S. K. Lee. 1995. A study of sikhye. Korean J. Food Nutr. 8, 165-171.

3. Cheng, M. H., and T. C. Jung. 1981. Effect of allithiamine on sacroma-180 tumor. Tai-wan L. Husuch Hui. Tsa. Chief. 80, 385-392.

4. Choi, D. J., S. J. Lee, M. J. Kang, H. S. Cho, N. J. Sung, and J. H. Shin. 2008. Physicochemical characteristics of black garlic (Allium sativum L.). J. Korean Soc. Food Sci. Nutr. 37, 465-471.

5. Han, E. H., T. S. Lee, B. S. Noh, and D. S. Lee. 1997. Volatile flavor components in mash of Takju prepared by using different nuruks. Korean J. Food Sci. Technol. 29, 563-570.

6. Jain, R. C. and C. R. Vyas. 1975. Garlic in alloxan-induced diabetic. J. Clim Nutr. 28, 681-684.

7. Jang, J. H. 1989. The history of Korean alcohol. Korean J. Dietary Culture 4, 271-274.

8. Jeong, J. W. and D. J. Park. 2006. Quality characteristics of loaf bread added with Takju powder. Korean J. Food Sci. Technol. 38, 52-58.

9. Joung, E. J., N. S. Paek, and Y. M. Kim. 2004. Studies on Korean Takju using the By-product of rice milling. Korean J. Food Nutr. 17, 199-205.

10. Jung, D. H. and H. G. Jung. 1985. Food analysis. pp. 197, Jin-ro. Co. Seoul.

11. Kilani, S, R. B. Ammar, I. Bouhlel, N. Hayder, A. Mahmoud, K. Ghedira, and L. Chekir-Ghedira. 2005. Investigation of extracts from (Tunisian) cyperus rotundus as antimutagens and radical scavengers. Environ. Toxicol. Phar. 20, 478-484.

12. Kim, A. R., S. Y. Lee, K. B. W. R. Kim, E. J. Song, J. H. Kim, M. J. Kim, K. W. Ji, I. S. Ahn, and D. H. Ahn. 2008. Effect of Glycyrrhiza uralensis on shelf-life and quality of Takju. Korean J. Food Sci. Technol. 40, 194-200.

13. Kim, J. H., S. H. Lee, N. M. Lee, S. Y. Kim, S. Y. Choi, J. Y. Yoo, and J. S. Lee. 2000. Manufacture and physiological functionality of Korean traditional liquor by using dandelion. Korean J. Appl. Microbiol. Biotechnol. 28, 367-371.

14. Kim, M. J., S. Y. Lee, K. B. W. R. Kim, E. J. Song, A. R. Kim, and J. H. Kim. 2007. Effect of chitosan on shelf-life and quality of Takju. J. Chitin Chitosan. 12, 198-204.

15. Kim, M. S., W. K. Lim, J. G. Cha, N. H. An, S. J. Yoo, and J. H. Park. 2001. The activation of PI3-K and PKC $\zeta$ in PMA-induced differentiation of HL-60 cells. Cancer Lett. 171, 79-85.

16. Kim, S. M. and W. K. Cho. 2006. Effects of Takju lees on the serum glucose levels in streptozotocin-induced diabetic rats. Korean J. Food Culture. 21, 638-643.

17. Lee, G. H. 1994. Characteristic and new technology of korean
Takju. Korean J. Appl. Microbiol. Bioeng. 7, 36-46.

18. Lee, J. S., T. S. Lee, S. O. Park, and B. S. Noh. 1996. Flavor cmoponents in mash of Takju prepared by different raw materials. Korean J. Food Sci. Technol. 28, 316-323.

19. Lee, S. K., I. H. Kim, and B. Y. Min. 1990. Effect of lysozyme and glycine on the Mageoly brewing process. J. Korean Agric. Chem Soc. 33, 252-256.

20. Lee, T. S. and J. Y. Choi. 1998. Volatile flavor components in Takju fermented with mashed glutinous rice and barley rice. Korean J. Food Sci. Technol. 30, 638-643.

21. Lee, T. S. and E. H. Han. 2000. Volatile flavor components in Takiu prepared by using Rhizopus japonicus Nuruks. Korean J. Food Sci. Technol. 32, 691-698.

22. Park, I. S., T. J. Kim, N. S. Kim, and B. S. Noh. 1996. Simultaneuous determination of glucose and ethanol of Takju by biosensor using dual cathode electrode. Korean J. Food Sci. Technol. 28, 974-980.

23. Park, J. H., S. M. Bae, C. Yook, and J. S. Kim. 2004. Fermentation characteristics of Takju prepared with old rice. Korean J. Food Sci. Technol. 36, 609-615.

24. Ryu, H. Y., E. J. Kum, K. H. Bae, Y. K. Kim, I. S. Kwun, and H. Y. Sohn. 2007. Evaluation for the antimicrobial, antioxidant and anti-thrombosis activity of Korean traditional liquors. Korean J. Food Sci. Technol. 35, 238-244.

25. Seo, S. B., S. M. Han, J. H. Kim, N. M. Kim, and J. S. Lee. 2001. Manufacture and physiological funtionality of wines and liquors by using pum (Prunus salicina). Korean J. Biotechnol. Bioeng. 16, 153-157.

26. Sharma, K. K. and S. P. Sharma. 1979. Effect of onion and garlic on serum cholesterol on normal subject. Mediscope. 22, 134-136.

27. Shashikanth, K. N., S. C. Basappa, and V. S. Murthy. 1981. Studies on the antimicrobial and stimulatory factor of garlic. J. Food Sci. Technol. 18, 44-47.

28. Shin, S. Y., S. H. Suh, W. D. Cho, H. K. Lee, and H. J. Hwang. 2003. Analysis of volatile components in Korean rice wine by the addition of Yulmoo. J. Korean Soc. Food Sci. Nutr. 32, 1206-1213.

29. Song, J. C. and H. J. Park. 2003. Takju brewing using the uncooked germed brown rice at second stage mesh. J. Korean Soc. Food Sci. Nutr. 32, 847-854.

30. Song, J. C., H. J. Park, and W. C. Shin. 1997. Changes of Takju qualities by addition of cyclodextriin during the brewing and aging. Korean J. Food Sci. Technol. 29, 895-900.

31. Swaffield, C. H., J. A. Scott, and B. Jarvis. 1997. Observations on the microbial ecology of traditional alcoholic cider storage vats. Food Microbiology 14, 353-361. 
초록 : 마늘 첨가 막걸리의 품질특성 및 항알레르기 효과

고유진 ${ }^{1}$ 강상동 ${ }^{1}$ 강상태 ${ }^{2} \cdot$ 류충호 $^{1}$ *

( ${ }^{1}$ 경상대학교 응용생명과학부(BK 21 프로그램) · 농업생명과학연구원, ${ }^{2}$ 초록보물섬)

본 연구에서는 다양한 기능성 및 생리활성 물질을 함유하고 있는 마늘의 활용방안을 제시하고 마늘 생산 농가 의 안정적인 소득과 수급조절 및 건강 기능 증진을 위하여 마늘을 이용한 마늘 첨가 막걸리를 개발하고 품질특성 및 항알레르기 효과를 확인하였다. 사용된 마늘의 수분함량은 $62.44 \%$, 총당 $15.31 \%$, 회분 $1.12 \%, \mathrm{pH} 6.4$, 총산은 $1.03 \%$ 로 마늘 첨가 막걸리의 총당, 환원당 함량, 총산 및 아미노산도는 다소 높게 나타났고 알코올 함량에 있어서 대조구에 비해 $1 \%$ 정도로 높게 나타났다. 주요 유기산은 lactic, citric, malic, oxalic 및 succinic acid로 나타났으며 이 중 lactic acid 함량이 $203.2 \%$ 로 대조구에 비해 약 16 배 정도로 높게 나타났다. 마늘 첨가 막걸리의 total polyphenol 함량, DPPH 자유라디칼 소거 활성 및 total thiosulfate는 대조구 막걸리에 비해 다소 높게 나타났다. 이는 마늘에 함유되어 있는 유기 황 화합물 등에 의해 함량이 높게 나타난 것으로 사료된다. MTT 분석 결과 유의적인 차이를 보이지 않아 마늘 첨가 막걸리의 세포 독성은 없는 것으로 나타났으며, 알레르기 유발 및 예방효과를 확 인하기 위한 histamine 유리량을 측정한 결과 마늘 첨가 막걸리와 대조구 막걸리 모두 histamine 유리억제효과를 보였으며 마늘 첨가 막걸리에서 보다 높은 효과를 확인할 수 있었다. 관능검사 결과 색에 대한 기호도는 특유의 색을 유지하여 대조구에 비해 다소 낮게 나타났지만, 맛, 향 및 전체적인 기호도는 대조구 막걸리에 비해 마늘 첨가 막걸리가 우수한 것으로 나타났다. 따라서 마늘 첨가 막걸리는 국내 막걸리 시장의 다양성을 증대시키고 우수한 기능성으로 막걸리 시장의 활성화를 이어 갈 수 있을 것으로 사료된다. 또한 한국의 전통주로 자리매김 하기 위해서 저장성 연구 및 향기성분 분석, 제성기술 확립 등 연구가 수반되어야 할 것이다. 